\title{
Metode Membentuk Kesehatan Mental Siswa Melalui Kegiatan Ice Breaking
}

\author{
I Gusti Ayu Adi Rahayuni \\ STKIP Agama Hindu Amlapura \\ radhajayantam@gmail.com
}

DOI : $10.37329 /$ cetta.v3i2.459

\begin{tabular}{ll}
\hline Keywords: & Abstract \\
\cline { 1 - 3 } Ice Breaking; & Students' mental healt has decreased as a result of stress, depression, \\
Mental Healt & lack of rest time and high learning load. Then the best method is \\
& needed to reduce the poor of students' mental healt. Ice breaking is \\
& one of the methods in building students' mentality. The purpose of \\
& this study is to find out the right ice breaking technique in an effort to \\
& grow student mentality and the benefits of the application of ice \\
& breaking. In Technique Data analysis, used techniques with \\
& qualitative descriptive analysis. The conclusion of this study is, ice \\
& breaking is one of method that can be used to help the mental build of \\
& students so that students can follow the learning process with \\
& enthusiasm, fun and mentality of students formed properly. \\
\hline
\end{tabular}

\begin{tabular}{l}
\hline Kata Kunci: \\
\hline Ice Breaking; \\
Kesehatan \\
Mental \\
\hline
\end{tabular}

\begin{tabular}{l} 
Abstrak \\
\hline Kesehatan mental siswa mengalami penurunan sebagai akibat \\
dari stres, depresi, kurangnya waktu istirahat dan beban \\
belajar yang tinggi. Maka diperlukan metode yang tepat untuk \\
mengurangi buruknya kesehatan mental siswa. Ice breaking \\
menjadi salah satu metode dalam menumbukan mentalitas \\
siswa. Tujuan penelitian ini adalah mengetahui teknik ice \\
breaking yang tepat dalam upaya menumbuhkan mentalitas \\
siswa serta manfaat yang diperoleh melalui penerapan ice \\
breaking. Teknik analisis data dengan analisis deskriptif \\
kualitatif. Kesimpulan penelitian ini adalah, ice breaking \\
menjadi salah satu metode yang dapat digunakan untuk \\
membantu pembentukan mental siswa sehingga siswa dapat \\
mengikuti proses belajar dengan bergairah, menyenagkan dan \\
mentalitas siswa terbentuk dengan baik.
\end{tabular}

\section{Pendahuluan}

Era 4.0 ditandai dengan semakin maju dan berkembangnya ilmu pengetahuan dan teknologi. Perkembangan dan kemajuan tersebut dibarengi pula oleh 
meningkatnya berbagai persoalan kehidupan manusia, termasuk kesulitan finansial, lapangan pekerjaan, pendidikan, pergaulan dan lain sebagainya. Mereka yang tidak siap menghadapi kecepatan perubahan ini akan terjebak pada situasi penuh pertentangan. Gejala yang ditimbulkan sebagai bentuk pertentangan tersebut salah satunya adalah stres. David Berceli, Ph.D seorang pakar internasional dalam bidang intervensi trauma, menjelaskan stres merupakan gangguan perasaan berupa perasaan cemas, tegang, takut dan khawatir yang disebabkan karena adanya ketidakseimbangan antara tuntutan dan kemampuan yang dibarengi dengan ketegangan emosional. Sehingga, berpengaruh terhadap kondisi fisik maupun mental seseorang (Berceli, 2015). Apabila tidak segera ditangani, tidak menutup kemungkinan gangguan perasaan atau stress akan menimbulkan gangguan kesehatan serius dan pada tingkat akut akan memberikan dorongan bagi individu yang bersangkutan untuk bertindak tidak rasional.

Tindakan irasional yang dominan menghasut diri seseorang untuk segera dapat keluar dari permasalahan yang dihadapinya adalah dengan melakukan tindakan bunuh diri. Bunuh diri telah dipandang sebagai salah satu penyelesaian masalah. Bagi sebagian orang, bunuh diri telah menjadi satu-satunya jalan menuju solusi dari masalah hidup yang menekan. Bagai melihat melalui celah pipa, tidak ada harapan dan penyelesaian lain yang tersisa. Sakit yang dirasakan dan pikiran yang berkecamuk sungguh tak bisa lagi dibendung. Mereka melihat tidak ada titik terang di masa depan dan sulit bagi mereka menemukan alasan untuk hidup lebih lama lagi. Mengakhiri hidup menjadi alternatif untuk bebas dari masalah hidup.

Bunuh diri kini telah menjadi suatu masalah global. WHO menyebutkan, 1,4\% kematian di seluruh dunia disebabkan oleh bunuh diri. Sebanyak 800 ribu orang di seluruh dunia tewas akibat bunuh diri setiap tahunnya. Itu artinya, setiap 40 detik ada satu orang yang tewas akibat bunuh diri. Sedangkan untuk di Indonesia sendiri, tingkat bunuh diri Indonesia berada pada angka 3,7 angka tersebut menempatkan Indonesia berada di peringkat 159 dalam hal tingkat bunuh diri di dunia. Bahkan bila dikaji lebih klasifikasi lagi pada rentangan usia, diketahui angka bunuh diri terbanyak berada pada usia 15-29 tahun.

Data tersebut jelas menunjukan, angka bunuh diri terbesar justru paling banyak dilakukan oleh kaum usia muda. Oleh sebab itu, WHO menetapkan bunuh diri menjadi pembunuh nomor dua di dunia (Detik, 2019). Dewan Pakar Bakeswa (Badan 
Kesehatan Jiwa Indonesia) yaitu dr. Nova Riyanti Yusuf S.PKj dalam hasil penelitian yang ia lakukan pada sejumlah remaja di DKI Jakarta, juga menyimpulkan hal yang sama, bahwa kaum usia muda pada usia 14 tahun justru sudah menunjukan tandatanda stres seiring dengan dinamika sosial dan tekanan dari lingkungan sekitar (JPNN, 2019).

Usia 14-29 tahun terkategori sebagai golongan usia muda, rata-rata sebagai pelajar hingga mahasiswa. Menjadi Tanya besar, mengapa kaum yang berada pada usia pelajar dan mahasiswa ini justru menjadi kaum yang paling banyak mengalami gangguan mental, depresi, stress hingga berujung pada upaya dan tindakan bunuh diri. Guna menjawab permasalahan tersebut, peneliti melakukan wawancara dan observasi terhadap 100 responden, yang mencakup pelajar atau mahasiswa dan para pekerja produktif pada rentangan usia 14-29 tahun. Kaum pelajar SMP, SMA dan mahasiswa menjadi responden dikarenakan usia responden yang merupakan usia yang paling rentang mengalami guncangan mental sesuai dengan data yang dikeluarkan oleh WHO. Guna menggali informasi awal terkait penyebab kaum usia muda rentan terpapar depresi atau gucangan mental, peneliti melakukan wawancara dan observasi pada 100 responden, yang terdiri dari pelajar SMP, SMA (sekolah swasta dan negeri), dan mahasiswa.

Berdasarkan hasil wawancara terhadap 100 responden diketahui bahwa, terdapat beragam alasan atau penyebab kaum usia muda yang notabena adalah para pelajar ini mengalami depresi, diantaranya karena ketatnya persaingan dalam mencapai prestasi, sejumlah tekanan guna meningkatkan dan mempertahankan prestasi akademik yang ditunjukkan dengan perolehan nilai yang dituntut melebihi nilai KKM, banyak dan bervariasinya tugas sekolah, ulangan tengah semester, hingga Ujian Nasional. Siswa juga merasa salah memilih jurusan, nilai yang kurang memuaskan, ancaman droup out, adaptasi dengan lingkungan baru, pengaturan waktu yang kacau, manajemen diri yang kurang bagus, tuntutan untuk mandiri, masalah finansial, gangguan hubungan interpersonal, konflik dengan teman, guru, pacar dan keluarga. Selain itu pula, tuntutan kehidupan, baik dari dalam maupun dari luar sekolah, menuntut kaum pelajar untuk dapat menghadapi permasalahan yang timbul dengan lebih mawas diri, bertanggung jawab, tangguh dan kuat.

Sekolah adalah basis utama pendidikan mental dan karakter anak justru menjadi wilayah yang berpotensi besar dalam meruntuhkan mentalitas tumbuh kembang anak. 
Beban belajarnya semakin tinggi, proses belajar mengajar yang dirasa kurang menyenangkan pada beberapa guru pengampu mata pelajaran, jadwal pembelajaran yang padat ditambah dengan tugas dari masing-masing mata pelajaran yang beragam, les maupun praktek keterampilan menambah padatnya jadwal belajar siswa dan mengurangi waktu refresing atau waktu istirahat siswa. Sejumlah keluhan tersebut berakibat pada penurunan gairah siswa dalam mengikuti proses pebelajaran. Hal ini di buktikan dari tingkat kehadiran siswa, yang masih sering tidak masuk sekolah. Tahun 2019 data ketidak hadiran siswa baik karena membolos maupun karena keluhankeluhan fisik seperti sakit meningkat hingga 60\%. Meningkatnya jumlah siswa yang sering kali terlambat masuk sekolah mencapai $65 \%$.

Setelah ditelusuri peneliti mendapat keterangan dari responden, rata-rata keterlambatan siswa karena tidak bergairah dalam mengikuti proses pembelajaran, bangun kesiangan karena harus mengerjakan tugas sekolah hingga larut malam dan juga kelelahan yang siswa alami karena padatnya aktivitas di sekolah. Guru pun juga mengeluhkan siswanya yang tidak fokus selama proses pembelajaran dan daya tangkap siswa yang lambat. Ditambah lagi dengan kondisi emosi siswa juga nampak tidak stabil, hal ini dilihat dari berbagai konflik yang terjadi antara siswa, kurangnya kendali diri siswa yang berujung pada perkelahian antar siswa dan kasus bully menjadi sederet kasus yang tidak ada habisnya ditangani oleh BK (Bimbingan Konseling). Kasus dan berbagai keluhan tersebut, adalah tanda bahwa siswa berada pada titik emosi yang tidak stabil akibat dari kurangnya waktu rileksasi, dan siswa merasa jenuh terhadap segala aktivitas di sekolah.

Segala bentuk permasalahan yang dihadapi oleh para siswa tersebut dapat diamati dari aktivitas para pelajar yang kurang bersemangat saat mengikuti pelajaran, murung, nampak cemas, takut dan temperamental atau mudah marah. Selain itu, para responden juga mengaku sering kali mengalami maag, sakit perut, debar jantung cepat, nyeri otot utamanya pada punggung, sakit kepala, anggota tubuh bergetar, berkeringat, dan mengalami gangguan makan. Gejala tersebut merupakan efek dari ketidakstabilan kondisi psikis, sehingga munculah sejumlah gangguan fisik.

Sebagaimana sejumlah fakta yang ditemukan di lapangan, ternyata gejala-gejala yang dikeluhkan oleh para responden adalah gangguan psikosomatis, yaitu suatu keluhan fisik yang disebabkan oleh kondisi emosional atau mental seperti stress. Penelitian yang dilakukan oleh (Apriyani, 2018) tentang faktor-faktor penyebab 
psikosomatis menyatakan, gangguan psikosomatis nyatanya dominan dipengaruhi oleh pikiran-pikiran yang diliputi oleh rasa cemas, takut, khawatir dalam menghadapi masalah tertentu, sehingga kondisi pikiran tersebut justru memengaruhi kondisi psikis dan fisik seseorang sehingga memunculkan berbagai kondisi emosi (sedih, cemas, kecewa, bahagia, takut, depresi) hingga pada keluhan fisik,(maag, sakit kepala, gangguan pencernaan dan lain sebagainya).

Tentunya, untuk mengatasi masalah mental utamanya yang dialami oleh para siswa, perlu ditangani langsung oleh ahlinya seperti dokter, pakar psikolog, psikiater atau terapis di bidang penyakit mental. Biaya yang dikeluarkan pun juga tidaklah sedikit. Jika masalah ini dibiarkan berlarut-larut, akibat yang ditimbulkan bisa fatal dan memepengaruhi daya tumbuh dan kembang pada mental siswa. Jadi, sangat dibutuhkan suatu penanganan yang efektif, efesien serta ekonomis dan tentunya cara yang ditawarakan pun mudah untuk diduplikasi sehingga siapapun dapat dengan mudah mempraktekannya. Menjawab permasalahan yang ada, maka proses pembelajaran kini seharusnya berpegang pada konsep belajar yang menyenangkan, proses belajar yang sehat dalam tumbuh kembang pada mentalitas siswa. Mengetahui sejumlah permasalahan yang terjadi dalam pembentukan pertumuhan mentalitas anak, maka perlu dilakukan sejumlah pembaharuan dalam kegiatan pembelajaran guna menyembuhkan sekaligus membentuk kembali kesehatan mental pada diri anak. Salah satu metode yang dapat digunakan untuk membentuk kesehatan mental pada diri anak adalah melalui Ice Breaking.

Secara umum, ice breaking dikenal sebagai salah satu metode pemecah kebekuan atau peralihan dari rasa bosan, mengantuk, tegang ataupun jenuh. Metode ice breaking yang dapat disematkan dalam proses pembelajaran apakah hanya untuk mengalihkan perasaan bosan, canggung, mengantuk, stres atau jenuh saja. Ice breaking yang di dalamnya digabungkan dengan tekni-kenik gerakan tertentu dapat membantu memulihkan mentalitas anak. Kegiatan Ice Breaking adalah salah satu teknik yang dapat digunakan dalam membantuk proses pembentukan sehat mental pada siswa. Bagaimana metode Ice Breaking dapat membantu membentuk kesehatan mental pada diri anak, bagaimana pula penerapannya,serta apa saja manfaatnya akan dipaparkan lebih jauh pada pembahasan. 


\section{Metode}

Jenis data dalam penelitian ini adalah data kualitatif. Metode pengumpulan data dilakukan dengan studi dokumentasi yaitu, dengan membaca sejumlah bahan kajian seperti jurnal hasil penelitian. Teknik analisis yang digunakan dalam penelitian ini adalah analisis deskriptif kualitatif. Penelitian deskriptif kualitatif dilakukan untuk menggambarkan hal yang sebenarnya mengenai variable dengan mengambil data yang telah terkumpul dan membuat analisa kesimpulan secara sistematis dan akurat.

\section{Hasil dan Pembahasan}

Ice Breaking adalah padanan dua kata Inggris yang mengandung makna "memecah es". Istilah ini sering dipakai dalam training, seminar, ataupun pelatihan dengan maksud menghilangkan kebekuan-kebekuan di antara orang-orang yang berada dalam suatu ruang, sehingga mereka saling mengenal, mengerti dan bisa saling berinteraksi dengan baik antara satu dengan yang lainnya. Musyafa (2018) mengungkapkan, Ice breaking juga dapat diartikan sebagai perlihan situasi dari yang membosankan, tegang, stress, menjenuhkan menjadi keadaan rileks, santai, bersemangat, serta memunculkan rasa gembira. Penerapan Ice breaking dibagi menjadi beberapa macam yaitu, dalam bentuk permainan, senam, tepuk tangan, lagu kreatif, humor, dan tebakan. Berbagai jenis ice breaking bertujuan untuk mengembalikan konsentrasi siswa, mengembalikan suasana menjadi hidup, dan menyenangkan. ice breaking adalah salah satu alternatif dalam membentuk mentalitas anak. Mengingat stress, depresi, minder, tidak percaya diri, rendah diri, adalah berbagai dampak dari berbagai pengalaman yang dialami oleh siswa dan adalah gangguan kesehatan mental.

Penerapan Ice breaking akan lebih efektif dalam upaya mengubah suasana hati, sekaligus kondisi mental seseorang apabila di dalamnya terdapat teknik gerakan olah tubuh, sekaligus afirmasi, dan gerakan-gerakan dinamis yang dapat memberi reaksi langsung terhadap kondisi psikis seseorang.Anthony Robbins dalam bukunya yang berjudul Awaken the Giant Within (2013: 181) menyatakan, "Our Emotion Created by Our Motion" emosi kita diciptakan oleh gerakan kita. Pernyataan tersebut menegaskan bahwa, gerak tubuh seseorang nyatanya dapat mengubah keadaan pikiran dan kondisi emosi seseorang. jadi, apabila seseorang diliputi perasaan seperti sedih, takut, marah, maka hanya dengan mengubah gerak tubuhnya saja emosi sedih itu dapat seketika 
digantikan dengan perasaan bahagia, ceria, semangat dan emosi-emosi yang memberdayakan lainnya.

Kondisi psikis seseorang yang diliputi oleh emosi berupa rasa cemas, khawatir, takut, marah, kecewa, sedih, bahagia, senang, antusias dapat dipengaruhi oleh gerakan tubuh seseorang. Sebagai contoh, ketika pikiran seseorang diliputi oleh kondisi emosi berupa perasaan sedih, tubuh akan menunjukan reaksi gerak berupa tubuh membungkuk, wajah ditekuk kebawah, dahi mengkerut, kaki menutup ke dalam, bahu menutup ke dalam, dan tangan menyentuh dada. Sikap tubuh tersebut adalah pola gerak yang dominan diperlihatkan oleh seseorang dalam kondisi sedih, tertekan, frustasi dan depresi. semakin gerakan tersebut dipertahankan, semakin seseorang akan larut dalam kondisi emosi depresi, sedih, frustasi.Begitu juga sebaliknya, jika seseorang berada dalam emosi bahagia, antusias, bersemangat, pola gerak yang muncul adalah, wajah tersenyum lebar, dada membusung, tubuh tegak, mata melotot, tangan terbuka lebar dapat pula tangan mengepal dan wajah mendongak ke atas, dalam ekspresi yang lebih bahagia seseorang mengekspresikan gerakan meloncatloncat.

Sangat jelas perbedaan bahasa tubuh antara seseorang yang sedang diliputi emosi atau rasa sedih, tertekan, depresi dengan orang yang diliputi oleh rasa bahagia dan suka cita. Berita baiknya, kondisi emosi seseorang dapat diubah dengan seketika dengan megubah gerak tubuhnya. Itu artinya, teknik ini akan sangat bermanfaat apabila diterapkan pada siswa yang berada pada kondisi emosi yang negatif selama mengikuti proses pembelajaran. Jika siswa selama ini tidak bersemangat dalam menerima pelajaran, merasa tertekan, murung, cemas, takut, sedih dan berbagai respon emosi yang melemahkan lainnya, emosi-emosi tersebut dapat seketika diubah hanya dengan mengubah gerak tubuhnya. Oleh karena itu diperlukan formulasi gerak yang dapat dengan seketika megubah suasana emosi seseorang. Untuk itu, metode ice breaking yang tepat perlu diupayakan guna memperoleh hasil yang relevan, jadi bukan sakadar gerakan-gerakan yang sifanya peralihan semata.Komposisi yang tepat dalam menerapkan kegiatan ice breaking adalah dengan membuat kombinasi yang tepat yaitu melibatkan gerakan dinamis, terdapat pula afirmasi positif, gerakan tubuh yang memicu perubahan perasaan serta musik. 
Pada penerapan Ice breakingyang tepat, siswa diajak untuk merileksasikan tubuh terlebih dahulu dengan teknik menarik nafas dan membuang nafas dengan teratur. Tujuan teknik pernafasan ini adalah menghirup oksigen dengan mengambil napas panjang sehingga dapat membantu terbukanya paru-paru. Tubuh akan memberikan tanda untuk memperlambat reaksi di otak. Kemudian ini dapat memperlambat denyut jantung dan menurunkan tekanan darah yang tinggi. Sehingga otak akan terasa lebih rileks dan tenang. Jika dirasa sudah mulai rileks, siswa diajak untuk menikmati music DJ atau jenis aliran music empowering atau jenis music lainnya. Music yang diperdengarkan adalah musik yang mampu mendorong seseorang bergairah dan bersemangat, serta music yang di dalamnya mengandung kata-kata positif. Sambil diiringi music, siswa diajak untuk berdiri sambil melakukan beberapa gerakan sesuai dengan tempo music. Gerakan-gerakan tersebut dibagi menjadi dua gerakan diantaranya, gerakan wajah dan gerakan olah tubuh.

Gerakan wajah yang dimaksud adalah gerakan-gerakan yang dapat memberikan pengaruh terhadap otot-otot wajah. Adapun gerakan otot wajah yang dimaksud adalah, tersenyum lebar, mata melotot, mata melirik kearah pojok bawah, mata berputar searah jaruh jam dan mata berputar berlawanan arah jarum jam. Gerakan tersenyum lebar akan menggerakan 400 otot wajah dan hal ini akan meningkatkan jumlah hormon endorphin yang beredar dalam tubuh. Hormon endorphin ini akan memberikan efek rileks, nyaman, dan bahagia. Membawa kondisi siswa dalam keadaan rileks akan dapat memberikan pengaruh terhadap kemampuan siswa dalam memecahkan persoalan-persoalan apapun, kondisi apapun, dan pertanyaan tersulit apapun. Selain itu, terdapatgerakan bola mata ternyata memberikan efek terhadap daya konsentrasi siswa.

Gerakan kedua adalah gerakan olah tubuh yang terdiri dari gerakan-gerakan dinamis seperti bertepuk tangan, gerakan melompat, gerakan menempuk dada, gerakan merentangkan tangan ke samping dan ke atas. Sejumlah gerakan tersebut dikolaborasikan menjadi gerakan yang berpola. Dampak nyata dengan memperaktikkan gerakan tersebut adalah kondisi emosi seseorang dengan seketika dapat diubah. Ditambah dengan memperdengarkan musik gerakan ini akan menjadi gerakan yang mengasyikan, membangkitkan gairah dan semangat dengan seketika. Tiap gerakan tersebut terinspirasi dari gerakan-gerakan tubuh saat seseorang merasa dalam kondisi bahagia, rileks, nyaman, dan bersemangat. 
Gerakan lainnya juga terinspirasi dari bahasa tubuh hewan, seperti gorilla. Gorilla sering kali menepuk dadanya, ini adalah bahasa tubuh yang menunjukan rasa gembira, dan rasa percaya diri. Menduplikasi gerakan hewan primata tersebut, adalah untuk memberikan efek secara langsung terhadap respon pada otak untuk segera mengubah pola emosi negatif menjadi positif.

Gerakan selanjutnya, yaitu gerakan tepuk tangan. Gerakan tepuk tangan merupakan gerakan yang menunjukan respon terhadap hal indah, penghargaan dan rasa hormat akan sesuatu. Pada saat bertepuk tangan terdapat 28 titik tekanan pada tangan yang terstimulasi seperti diungkapkan Rahul Dogra dari Kairali Ayurveda, India (Barceli, David 2015: 35), titik-titik tersebut terhubung dengan organ-organ tubuh sehingga lewat tepuk tangan organ tersebut mendapat rangsangan. Bertepuk tangan juga dapat membantu melancarkan dan meningkatkan sirkulasi darah pada tubuh. Sirkulasi menyebabkan energi dalam tubuh semakin besar karena aliran darah yang dapat lebih banyak membawa oksigen ke seluruh tubuh. Lancarnya aliran oksigen ke otak dapat memberikan efek tenang, rileks, dan lebih konsentrasi.

Gerakan berikutnya adalah gerakanjumping atau melompat-lompat, gerakan ini pun juga memberikan pengaruh terhadap lancarnya aliran oksigen ke seluruh tubuh (Berceli, David. 2015). Gerakan selanjutnya adalah gerakan membusungkan dada sambil menegakan posisi tubuh. Gerakan ini akan dapat meningkatkan jumlah oksisgen dalam dada dan hal itu akan dapat membuat tubuh lebih segar.

Gerakan-gerakan tubuh tersebut dikolaborasikan menjadi satu kesatuan sehingga terbentuk pola gerakan dinamis, energik dan menggairahkan. Gerakan sederhana tersebut, sangat mudah diduplikasi dan dilakukan saat kapanpun. Gerakan sederhana tersebut tercetus dari berbagai yang diadapsi dari gerakan-gerakan hewan dan bahasa tubuh manusia ketika emosi berada pada kondisi positif. Gerakan tubuh nyatanya dapat mengubah emosi yang dihasilkan oleh kondisi pikiran seseorang. Seperti yang diungkapkann oleh (Robbins, 2013) "Our Emotion Created by Our Motion" emosi kita diciptakan oleh gerakan kita.

Ice Breaking sangat membantu siswa dalam seketika mengubah kecenderungan emosi negatif menjadi positif hanya dalam kurun waktu singkat. Gerakan dinamis tersebut, memicu kerja otak, kerja organ tubuh untuk meningkatkan kadar endorphin di dalam tubuh. Gerakan dinamis dan menyenangkan tersebut mampu melancarkan dan meningkatkan sirkulasi darah pada tubuh. Sirkulasi menyebabkan energi dalam 
tubuh semakin besar karena aliran darah yang dapat lebih banyak membawa oksigen ke seluruh tubuh. Lancarnya aliran oksigen ke otak dapat memberikan efek tenang, rileks, dan lebih konsentrasi. Gerakan dinamis yang dipraktekkan oleh siswa dalam ice breakingmenjadikan suasana kelas dipenuhi oleh tawa, keceriaan dan optimisme. Ditambah dengan music yang diperdengarkan adalah music yang sifatnya dinamis akan membawa siswa lebih terhanyut lagi dalam suasana gairah dan optimisme yang dipacarkan oleh suasana kelas.

Poin yag tidak kalah pentingnya agar ice breaking yang diterapkan optimal adalah dengan menyisipkan teknik afirmasi di dalamnya. Sambil bergerak siswa diajak melakukan afirmasi diri dengan menyebutkan kata-kata opstimis. Afirmasi adalah pernyataan-pernyataan positif dan spesifik yang ditujukan kepada diri sendiri. Katakata afirmasi yang di sertakan merupakan kata-kata positif, optimis dan kata-kata yang menyemangati. Sambil melakukan jumping, siswa diajak mengepalkan tangan ke atas sambil melakukan afirmasi kata-kata positif,

“Gooooo...Goooo...Gooooo...!”, “aku bisa...!", “aku luar biasa...!”, “aku sukses...!”, "aku hebat...!", “Aku bahagia..!”Afirmasi seperti kata-kata tersebut secara kompak di ucapkan oleh siswa saat ice breaking berlangsung. Afirmasi pun dapat diucapkan dengan kata-kata positif lainnya, sesuai dengan kebutuhansiswa. Afirmasi ini bertujuan untuk merangsang pikiran agar fokus pada apa yang ingin diubah pada kondisi diri siswa. Teknik afirmasi menurut (Gunawan, 2012) salah seorang pakar pyscologis menyebutkan, afirmasi dapat membantu seseorang dalam memprogram pikiran bawah sadarnya. Sebab afirmasi adalah adalah self-talk yang diucakan kepada diri sendiri dan merupakan salah satu bentuk pemrograman ulang pikiran. Melalui pemrograman pikiran lewat afirmasi, sangat mujarab untuk membantu pecapaian optimisme siswa baik dalam belajarnya ataupun dalam kesehtan mentalnya. Teknik afirmasi yang tepat pun juga dijabarkan oleh Adi W. Gunawan, yaitu dengan memanfaatkan rileksasi pikiran.

Semakin siswa diajak untuk rileks, semakin afirmasi postif yang diperdengarkan akan memberikan efek pada pemrograman pikiran siswa. Sehingga dengan ucapan ataupun kata-kata yang membangun tersebut, tumbuh kesadaran serta keyakinan pada diri siswa bahwa segala bentuk tantangan yang dihadapi akan mampu terlampaui. Teknik ini juga secara langsung mengajarkan siswa untuk terus memupuk optimisme pada diri siswa agar selalu berucap hal-hal yang membangun, positif, kata- 
kata yang mampu menyemangati. Sebagai hasilnya, tentu kesehatan mental akan terbentuk. Jadi teknik ice breaking yang hendak diterapkan dalam proses pembelajaran di kelas, ataupun di luar kelas, hendaknya memperhatikan beberapa teknik yang telah dijabarkan. Gerakan dinamis, gerakan bahan tubuh serta afirmasi yang positif adalah tiga hal pokok yang wajib diperhatikan, sehingga ice breaking yang diterapkan dapat segera mengubah kondisi psikis seseorang dalam sekejap.

Perlu untuk di perhatikan, gerakan ice breaking yang diterapkan tentunya bukanlah teknik penyembuhan bagi orang yang mengalami depresi akut, ataupun keadaan psikis yang terkategori berat. Jika kondisi psikis anak sudah terkategori akutmaka diperlukan penanganan lebih lanjut dari para pakar kesehatan pyscologis. Penerapan metode ice breaking dalam skala psikis ringan atau tidak berat sangat membantu jika diterapkan dengan teknik dan pola yang benar. Oleh sebab itu, para pendidik, dalam proses mengelola kelas perlu sedianya memperhatikan kebutuhan psikis siswa melalui kegiatan ice breaking.

Sebagaimana telah dipaparkan pada pembahasan di atas, ice breaking dapat memberikan sejumlah manfaat diantaranya, menghilangkan kebosanan, kejemuan, kecemasan, dan keletihan karena bisa keluar sementara dari rutinitas pelajaran dengan melakukan aktivitas gerak bebas dan ceria. Dalam penerapan ice breaking yang benar, dapat pula melatih berpikir secara kreatif dan luas siswa, mengembangkan dan mengoptimalkan otak dan kreativitas siswa. Ice breaking juga mampu melatih siswa berinteraksi. Melatih berpikir sistimatis dan kreatif untuk memecahkan masalah. meningkatkan rasa percaya diri, melatih menentukan strategi secara matang, melatih kreativitas dengan bahan yang terbatas, melatih konsentrasi, berani bertindak dan tidak takut salah, serta memantapkan konsep diri.

Ice breaking berfungsi mengelola kesehatan mental pebelajar. Kesehatan mental merupakan keadaan di mana kepribadian, emosional, intelektual dan fisik seseorang dapat berfungsi optimal, mampu beradaptasi terhadap tuntutan lingkungan dan stressor, menjalankan kapasitasnya selaras dengan lingkungannya, dapat menerima diri sendiri, mampu menyesuaiakan diri dengan lingkungannya, terus menerus bertumbuh, berkembang dan matang, dapat menerima kekurangan atau kelemahannya, mampu mengendalikan dan menghadapi persoalan, memiliki kepuasan dalam kehidupan sosialnya (Kalimantusyaro, 2018). Kriteria yang sangat penting dan dapat digunakan untuk menilai kesehatan mental yaitu pengendalian, integrasi pikiran dan tingkah laku, 
integrasi motif-motif dan pengendalian konflik atau frustrasi, perasaan-perasaan dan emosi yang positif dan sehat, ketenangan atau kedamaian pikiran, sikap-sikap yang sehat, Konsep diri (Self Consept) yang sehat, identitas ego yang adekuat, hubungan yang kuat dengan kenyataan (Yustinus, 2006: 52). Oleh karena itu, ice breaking ini sangat penting disisipkan dalam aktivitas pembelajaran.

\section{Kesimpulan}

Ice breaking menjadi salah satu alternatif yang dapat mengurangi stress, depresi, dan menumbuhkan mentalitas anak, melalui metode afirmasi kata-kata positif, gerakan dinamis, serta dikombinasikan dengan music. Kolaborasi tersebut akan menghasilkan gerakan dinamis yang dapat merangsang tumbuhnya perasaan menyenagkan, membahagiakan, kenyamanan, rileks, serta memacu semangat dan optimisme pada diri siswa.

\section{DAFTAR PUSTAKA}

Apriyani, Ratih. 2018. Faktor-faktor Penyebab Psikosomatis Pada Orang dengan Kecenderungan Psikosomatis Di Samarinda. Ejournal Psikologi 6 (3). 610-617. Tersedia pada http:/ / ejournal.psikologi.fisip-unmul.ac.id.

Berceli, D. 2015. Tension and Trauma Releasing Exercises. Jakarta: Sinotif Publishing.

Detik, N. 2019. Tingkat Bunuh Diri Indonesia Dibanding Negara-Negara.

Tersedia pada https://news.detik.com/berita/d-4391681/tingkat-bunuhdiriindonesia. Diakses 21 Juni 2019.

Gunawan, A, W. 2012. Becoming A Money Magnet. Jakarta: PT Gramedia Pustaka Utama.

JPNN. 2019. Dokter Nova Riyanti: Remaja Milenial Rentan Bunuh Diri. Tersedia pada https://www.jpnn.com/news/dokter-nova-riyanti-remaja-milenial-rentan. Diakses 21 Juni 2019.

Kalimantusyaro. 2018. Pengaruh Kesehatan Mental, Motivasi Belajar dan Kedisiplinan Belajar Terhadap Prestasi Belajar Peserta Didik Di Madrasah Ibtidayah Salafiyah Bahauddin Taman Sepanjang Sidoarjo. Tesis. Tersedia pada http://digilib.uinsby.ac.id. Diakses 5 Juni 2019.

Robbins, A. 2013. Awaken The Giant Within. Jakarta Selatan: PT. Ufuk Publishing House. Yustinus, S. 2006. Kesehatan Mental 1. Yogyakarta: Kanisius. 